(2) Open Access Full Text Article

\title{
Hypersensitive reactions to local dental anesthetics and patient information: critical review of a drug leaflet
}

This article was published in the following Dove Press journal:

Local and Regional Anesthesia

26 September 2011

Number of times this article has been viewed

\section{Daniel Simonet}

School of Business and Management, American University of Sharjah, Sharjah, United Arab Emirates
Correspondence: Daniel Simonet School of Business and Management, American University of Sharjah, PO Box 26666, Sharjah, United Arab Emirates Tel +97 I6 5 I5 2373

Fax +97 I6 5585065

Email dsimonet@aus.edu
Abstract: This paper discusses the case of a patient who experienced adverse reactions to a local anesthetic. It reviews symptoms of adverse reactions, possible causes, patient management, and alternative anesthesia modes. The second part of the paper discusses the product leaflet information and the associated legal issues.

Keywords: hypersensitive reactions, local dental anesthetics, patient information

\section{Introduction}

Various surveys indicate that the number of deaths attributed to local anesthesia ranges from $1: 1,500,000$ to $1: 4,000,000 .{ }^{1}$ While adverse reactions to local anesthetics are a reality, ${ }^{2,3}$ a true immunologic reaction to a local anesthetic is rare. ${ }^{4}$ Allergies to amide caines are extremely rare. Still, there are some documented cases..$^{5-7}$ Complications are not uncommon. Daubländer et $\mathrm{al}^{8}$ found an overall incidence of complications of $4.5 \%$. In a prospective survey of serious complications resulting from locoregional anesthesia in 100,000 patients, there were 15 cases of convulsions arising from 21,278 peripheral blocks. These were always preceded by prodromes, and never followed by cardiac arrest. There was one case of cardiac arrest, and no allergy. The absence of a cardiac arrest after a neurotoxic event is most likely to be the result of a quick response to breathing distress (ie, oxygen therapy with mask, intubation). ${ }^{9}$ According to the SOS Regional Anesthesia Hotline report, there have been 56 reports of serious complications in 158,083 patients undergoing locoregional anesthesia. This article discusses the case of a patient who has experienced adverse reactions and sideeffects for Articaine. ${ }^{10-12}$

This paper does not focus on true allergic reactions to local anesthetics, which are extremely rare. ${ }^{4}$ Allergic reactions can vary widely in symptoms and intensity, even in the same patient. However, this patient experienced near-identical adverse reactions after two injections on separate occasions. The paper does not consider an allergic reaction to common preservatives, such as methylparaben (the dental cartridge did not contain methylparaben) nor a reaction to adrenaline that makes the numbing effect last longer (there was no adrenaline in the second injection).

\section{Background event}

A patient with no history of atopy had two anesthetic injections, one of $2 \%$ lignocaine with 1:80,000 adrenaline for a root canal procedure and another of articaine chlorhydrate (marketed as Septanest ${ }^{\circledR}$ in France and as Septocaine ${ }^{\circledR}$ in the US) for a tooth extraction. 
On the first occasion, a few seconds after the injection, the patient experienced abdominal pain, tachycardia, burning paresthesia on the feet, hands and face, hypertension, hyperpnea, tachypnea, and severe anxiety.

The same anesthetic (lignocaine) had been given a few days before without any adverse effect. Thus, the cumulative dose of local anesthetic could have led to systemic toxicity. As Lemay and et $\mathrm{al}^{13}$ reported "... a medication can be tolerated for a significant period of time before causing an accident". For example, in a different case, a patient had been given the same amount of the same preparation as Ultracain D-Suprarenin $^{\circledR} 2$ and 10 months earlier without any adverse effects. ${ }^{6}$

The second event (with Septocaine) occurred 9 months later. Septanest was administered without noradrenaline, following the recommendation of a cardiologist. However, the patient experienced the same symptoms and some additional symptoms including muscle pain, a sensation of heat, especially on the face, partial paralysis of feet, hands and throat, headache, dizziness, a loss of spatial orientation, and dysphonia. Tachycardia was less intense, but still present. The patient required admission to the emergency ward.

\section{Adverse reactions}

Adverse effects from local anesthetics include allergic and toxic reactions. ${ }^{1}$ Sodium metabisulphite, a vasoconstrictor preservative contained in articaine and lidocaine, can also cause allergic reactions in patients with sulphite sensitivity. An allergic reaction was excluded. Symptoms such as bradycardia, feeling of heat, and hypotension would point to a vagal mechanism, and treatment would then consist of prescription of antihistamines with a minor tranquilizer 2-3 hours before the dental procedure. However, the patient experienced tachycardia and hypertension (not hypotension). Malaise, feeling of heat, paresthesias, and polypnea could indicate spasmophilia. ${ }^{14,15}$ The patient had never had a spasmophilia episode before. The two crises he experienced happened only seconds after the caine drug was administered.

A differential diagnosis would be a neurotoxic reaction. Nonallergic adverse reactions are mostly of pharmacological or toxic origin, ${ }^{14}$ and symptoms such as tachycardia, hyperpnea, hypertension, convulsions, feeling of heat, paresthesias, dysphonia, confusion, headache, malaise, hand tremor, loss of spatial orientation, and vertigo suggest a neurotoxic reaction. ${ }^{9,16,17}$ The signs of neurotoxicity can be subjective (eg, paresthesias, especially in the distal areas, such as hands, feet and head, vertigo, loss of spatial orientation, anxiety, headache, feeling agitated) or objective (tachycardia, dysphonia, convulsions, and tremors in distal body areas and face). ${ }^{9,18,19}$ Tachycardia, hypertension, and tachypnea are known but uncommon side effects. The lidocaine package insert reports that " ... early unexplained signs of tachycardia, tachypnea, labile blood pressure and metabolic acidosis may precede temperature elevation". Symptoms such as tachypnea, hyperpnea, severe anxiety, vertigo, muscle weakness, and bone pain suggest metabolic acidosis. ${ }^{20}$ Acidosis and hypercapnia can trigger convulsions. ${ }^{16}$ The ultimate stage is coma, with potentially lethal consequences.

All anesthetic agents can induce convulsive accidents. ${ }^{21}$ As Mazoit ${ }^{16}$ reported, any anesthetist practicing locoregional anesthesia is confronted with convulsive symptoms every 800 to 1500 blocks. ${ }^{22,23}$ Complex partial crisis makes diagnosis difficult, and symptoms of a panic attack (eg, sensation of imminent death) can be concomitant with a neurotoxic reaction. These symptoms should not be attributed to psychological weakness or stress on the part of the patient, but should be recognized as a side effect of local anesthesia. ${ }^{9}$ Neurotoxicity is a medical emergency, with potentially long-lasting cerebral side effects and/or death. However, the only reported cases of convulsive accidents leading to death or having serious sequelae have taken place outside of the operating room (or an equivalent setting in terms of material and human equipment). ${ }^{24-26}$

\section{Package insert information}

Firstly, Septodont Inc (Paris, France), the company marketing Septanest $40 \mathrm{mg} / \mathrm{mL}$, downplays the adverse reactions caused by the drug. In particular, abdominal pain, feeling of heat, particularly on hands, feet and face, temporary paralysis of hand, foot and throat, dysphonia, loss of spatial orientation, burning paresthesias, hypertension, and thirst/ dry mouth, are not mentioned either in the package insert or on the company website in France. These symptoms are clinically important because abdominal pain, feeling of heat, particularly on hands and feet, and dysphonia, can suggest an allergic reaction. The absence of these symptoms on the package insert makes diagnosis of an allergic reaction difficult, including by a trained professional. Even if these symptoms are not allergy-related, they are significant signs of an anaphylactoid reaction.

Secondly, the list of adverse effects differs between countries. Septodont lists far fewer adverse effects on the product leaflet and company website in France compared with those listed in the US. On the US package insert for Septanest $40 \mathrm{mg} / \mathrm{mL}$, for epinephrine in particular, the list 
includes adverse and intercurrent events recorded in one or more patients $(\mathrm{n}=882)$, but which occurred at an overall rate of less than $1 \%$, and were considered clinically relevant, ie, abdominal pain, myalgia, facial paralysis, pruritus, asthenia, and vomiting, are listed on the company insert in the US, but not in France. Other reactions (eg, edema, skin disorders, thirst, constipation, diarrhea, taste perversion) are listed on the package insert in the US, but do not appear on the company website or product leaflet in France. While having multiple insert packages across non-European nations is legal, it raises major ethical issues.

Description of side effects for the same product, in this case Septanest $40 \mathrm{mg} / \mathrm{mL}$, differs across European countries, even between neighboring countries, eg, France and Belgium. While there are several warnings regarding the use of articaine $\left(\right.$ Septanest Normal $^{27}$ and Special ${ }^{28}$ ) in the Belgian leaflets, these are absent in the articaine leaflet for France (Septanest $40 \mathrm{mg} / \mathrm{mL}) .{ }^{29}$ The leaflet and company website in Belgium describes immediate or delayed hypersensitivity reactions to articaine, such as urticaria, edema, pruritus, and erythema, as well as diarrhea and wheezing. These significant side effects are not listed on the French leaflet.This is a potential violation of European Union law, that imposes similar labeling across all European Union countries. According to The Rules Governing Medicinal Products in the European Union (2001/83/EC) that compiles the body of European Union legislation in the pharmaceutical sector for medicinal products for human use: "The European Pharmacopoeia is a single reference work for the quality control of medicines in Europe. In case of doubt the official reference is the European Pharmacopoeia official publication rather than a national pharmacopoeia publication. All producers of medicines or substances for pharmaceutical use therefore must apply the quality standards of the European Pharmacopoeia for the marketing and use of these products in Europe".

Other serious side effects listed by the Bosscher Foundation $^{30}$ do not appear on the insert package in France. This organization states that articaine is a cause of neural intoxication in patients with butyrylcholinesterase deficiency, in whom articaine is not metabolized normally, causing severe adverse reactions. According to the Bosscher Foundation, ${ }^{30}$ "articaine accumulation has caused long-term damage to nerve functions, in particular the central nervous system". Among Caucasians, approximately $4 \%$ of individuals have butyrylcholinesterase deficiency. ${ }^{31}$ The Bosscher Foundation strongly advises against the use of articaine if the patient has not been tested for butyrylcholinesterase deficiency. In some countries, the information leaflet for Ultracain ${ }^{\circledR}$ (articaine hydrochloride is the active component of this product in the Netherlands, Belgium, Germany, and many other countries) contains the warning "Ultracain may not be administered to patients with cholinesterase deficiency, unless there are strict indications for its use. This is due to a possible prolonged working effect of Ultracain in these patients and in some cases extremely strong effects". ${ }^{32}$ This warning does not appear on information leaflets for products containing articaine hydrochloride in France. The dentist is unable to see if a patient has butyrylcholinesterase deficiency. Only in exceptional circumstances does an anesthesiologist carry out an enzyme test when a butyrylcholinesterase deficiency is suspected, such as when using certain muscle relaxants during operations, eg, succinylcholine. ${ }^{30}$

\section{Paresthesias}

The paresthesia rates listed for articaine raise questions regarding the use of this agent as a local anesthetic. According to Dower, ${ }^{33}$ ".... there is substantial evidence of the very significant increase in paresthesias with the use of articaine". A study by Miller and $\mathrm{Haas}^{34}$ concluded that the incidence of paresthesias for articaine was close to 1 in 500,000 injections. Haas and Lennon, ${ }^{10}$ in a 21-year retrospective study, reported that paresthesias occurred most often following the injection of articaine and prilocaine. ${ }^{10,35}$ The observed frequencies of paresthesias following the administration of articaine $(P<0.002)$ or prilocaine $(P<0.025)$ were significantly greater than the expected frequencies for these agents. The application submitted to the US Food and Drug Administration for regulatory approval of Septodont indicated there had been 21 cases of paresthesia in 882 patients. One report pointed to a relationship between inferior alveolar nerve block injections using articaine and an apparently increased incidence of prolonged dysesthesia. ${ }^{12}$ A peer-reviewed paper reported that articaine $4 \%$ had a paresthesia rate 20 times higher than that for lidocaine $2 \%{ }^{36}$ The increased paresthesia rate with articaine has been noted by government agencies (eg, the Danish Medicines Pharmacovigilance Agency, US Food and Drug Administration), dental insurance carriers (eg, the Dentists Insurance Company in 2005), ${ }^{37}$ professional bodies (eg, Royal College of Dental Surgeons of Ontario, Canada in 2005), and other organizations (eg, the Clinic Research Associates Foundation). The paresthesia rate for articaine is 1-2 in 80 profound inferior alveolar injections and 1-2 in 187 maxillary infiltrations. ${ }^{33}$ In 2005, the US Food and Drug Administration required a new paresthesia warning in the package insert. ${ }^{1}$ On at least three occasions, the US Food and Drug Administration has required changes to the product 
insert for articaine because of reports of adverse events. ${ }^{38}$ In Denmark, Hillerup and Jensen ${ }^{39}$ reported that articaine produced an incidence of injection injuries more than 20-fold higher than lidocaine. ${ }^{40}$ The British Dental Journal has also highlighted that prolonged paresthesias appear to occur more frequently with articaine. ${ }^{12,41}$ In the Food and Drug Administration study, it was reported that $38 \%$ of patients experienced pain or burning. The issue of paresthesias is also discussed in a published paper on the safety of articaine..$^{42}$ Furthermore, in 2001, Malamed et $\mathrm{al}^{43}$ reported a $0.9 \%$ incidence rate for paresthesias with articaine. According to the package insert in the US, "Persistent paresthesias of the lips, tongue, and oral tissues have been reported with use of articaine hydrochloride, with slow, incomplete, or no recovery". While there is a warning concerning paresthesias for Septanest $40 \mathrm{mg} / \mathrm{mL}$ containing adrenaline 1/100,000 in France, there is no mention of that risk on the company website or in the insert package for Septanest $40 \mathrm{mg} / \mathrm{mL}$ in France or for Septanest Special and Normal in Belgium.

\section{Patient follow-up and alternative modes of anesthesia}

An allergy test for articaine hydrochloride is recommended. Because a preservative can cause an allergic reaction, ${ }^{44}$ allergy to metabisulfite, the preservative used in articaine hydrochloride, must also be tested for. It is more common (albeit still relatively rare) for dental patients to be allergic to preservatives in a local anesthetic solution, although the prevalence in the general population is not known. If allergy to a preservative is confirmed, the patient should be treated with a preservative-free local amide anesthetic.

If skin testing cannot be performed, there is a wide range of alternative therapies. These include the use of a different caine or an ester agent. ${ }^{45}$ An allergist can help the patient to identify which of these agents he or he can tolerate among the five local anesthetics used in dentistry today, ie, lidocaine hydrochloride (Xylocaine ${ }^{\circledR}$, Alphacaine ${ }^{\circledR}$, Lignospan $^{\circledR}$, Octocaine $^{\circledR}$ ), mepivacaine hydrochloride (Carbocaine ${ }^{\circledR}$, Arestocaine $^{\circledR}$, Isocaine ${ }^{\circledR}$, Polocaine $^{\circledR}$, Scandonest $\left.^{\circledR}\right)$, prilocaine hydrochloride (Citanest), and bupivacaine hydrochloride $\left(\right.$ Marcaine $^{\circledR}$ ). Diphenhydramine can be used as an alternative to ester or amide local anesthetics in minor procedures of short duration. ${ }^{4}$ Anesthetics gas, opioids, general analgesia, and hypnosis, ${ }^{4}$ as well as sedation using antihistamines as a local anesthetic agent, ${ }^{1}$ are also alternatives to a local anesthesia.

\section{Legal implications}

The victim of damage caused by a product defect has two legal options: one is based on common law and the other one based on the legislation passed on May 19, 1998.

\section{Common law}

Regarding legal action against a manufacturer, the law is based on contractual liability (refer to the NIMAOL case, Rouen Court of Appeal, February 19, 1979) in that the manufacturer and retailer have an obligation to provide information and counseling. That obligation is limited to product side effects, contraindications, precautions, and warnings that are known at the time of introduction of the product to the market. This implicit contractual relationship means that the guarantee against hidden defects provides a basis for legal action, ie, whenever the product's hidden defects make it unsuitable for use (Court of Appeal, February 14, 1990, for a drug misused as a result of a lack of adequate medical literature). However, legal action based on hidden defects must be initiated rapidly by the plaintiff. In recent years, the law has become stricter for manufacturers, both in terms of responsibility for product safety, in light of jurisprudence and the legislation passed on May 19, 1998, and in terms of provision of information.

\section{Law of May 19, 1998}

Jurisprudence has decided that the seller and manufacturer of a pharmaceutical product have a contractual safety obligation, ie, they must deliver a product devoid of any defect that may create a danger to the patient (Court of Appeal, June 11, 1991, and Court of Appeal, March 3, 1998, a non-digestible tablet which, while in the victim's intestine, caused inflammation that required surgical intervention).

The law of May 19, 1998 transposes the European directive of July 25, 1985, on manufacturer liability for defective products under French law. It is not a substitute for the relevant common law, but an addition to it. The patient must act within three years, starting from the date he or she was informed or should have been informed of damages. The law suppresses producer responsibility 10 years after the product was put on the market. Once the delay has expired, the patient must prove the damage under common law.

Under the law of May 19, 1998, the victim must prove damage, the product defect, and the causal link between the defect and the damage. The defect is not presumed. The manufacturer can be held responsible for the defect even if the product has received market approval. ${ }^{46}$ 
In France, the directive of December 3, 2001, related to the general code on product safety, contains a general safety obligation, and provides a definition of "safe products", but does not change the law of May 19, 1998, regarding the manufacturer's responsibility. The jurisprudence extends responsibility to the manufacturer, in that as soon as harm is caused, the manufacturer's responsibility is engaged. This is in line with the European directive of July 25, 1985, ie, "manufacturer responsibility is engaged if it defaults on its obligation to provide a product devoid of any effect that can create a danger for a person or a good". The drug firm can be charged if the drug does not offer the safety the general public can legitimately expect, even if no fault has been characterized.

In addition to product safety, more emphasis has been put on the rights of patients and practitioners to have product information, such that the manufacturer must provide full information regarding product safety on the package insert and the Répertoire des Spécialités Pharmaceutiques. Any judgment concerning product safety takes into consideration the quality of the information provided to the patient via the package insert, ${ }^{47}$ and whether any further information provided could have prevented the accident.

As the 98-389 legislation explains "A product is defective if it does not offer the safety one can legitimately expect. In assessing the drug safety one can legitimately expect, it must be taken into consideration all circumstances and notably product presentation, its reasonable use and the time of its introduction ..." (article 1386-4 of the Civil Code), ${ }^{48}$ as exemplified with the Isoméride decision of justice. ${ }^{49}$ In this case, the manufacturer, Septodont, may be contravening that law because it omits to mention critical side effects (eg, myalgia, hypertension, abdominal pain, burning paresthesias) in the French package insert.

When undesirable effects occur, and these are not described in the product leaflet (as in the present case) and in the Répertoire des Spécialités Pharmaceutiques, a drug company is considered to be marketing a "defective product" and "is responsible for any damage caused by a defect of its product" (article 1386-1 of the Civil Code) if the causal relationship is admitted. ${ }^{50}$

\section{Conclusion}

Cases of hypersensitivity to local anesthetics are rare, but do raise ethical issues. Most manufacturers would probably assume that such cases are so rare that they do not warrant mention in the product leaflet. However, practitioners do need more information. Given that such cases are very rare, very few dentists would have the necessary experience with these reactions to manage them appropriately. Few dental practitioners are able to identify a neurotoxic reaction. Finally, while having different product leaflets across different markets is legal (material posted differs from country to country because each country has individual laws), it raises ethical concerns. Different markets imply different entitlements, eg, regarding access to information, for both patients and practitioners. However, within the European Union community, production information contained on the leaflet must be identical. Although the package insert is, by definition, a legal document more concerned with legality than providing peer-reviewed information, and case and patient studies, it must not ignore adverse effects, no matter how rare these are. Also, as product usage increases, adverse reactions become better known, and that knowledge should be better conveyed to practitioners and their patients.

\section{Acknowledgments}

The author would like to thank the creators of the following website: http://www.sos-net.eu.org/medical/index.htm and the patient association 'Rights for All'.

\section{Disclosure}

The author reports no conflicts of interest in this work.

\section{References}

1. Lu DP. Managing patients with local anesthetic complications using alternative methods. Pa Dent J (Harrisb). 2002;69:22-29.

2. Gall H, Kaufmann R, Kalveram CM. Adverse reactions to local anesthetics: analysis of 197 cases. J Allergy Clin Immunol. 1996;97: 933-937.

3. Berkun Y, Ben-Zvi A, Levy Y, Galili D, Shalit M. Evaluation of adverse reactions to local anesthetics: experience with 236 patients. Ann Allergy Asthma Immunol. 2003;91:342-345.

4. Eggleston ST, Lush LW. Understanding allergic reactions to local anesthetics. Ann Pharmacother. 1996;30:851-857.

5. El-Qutob D, Morales C, Peláez A. Allergic reaction caused by articaine. Allergol Immunopathol (Madr). 2005;33:115-116.

6. Malanin K, Kalimo K. Hypersensitivity to the local anesthetic articaine hydrochloride. Anesth Prog. 1995;42:144-145.

7. Maccoll S, Young ER. An allergic reaction following injection of local anesthetic: a case report. J Can Dent Assoc. 1989;55:981-984.

8. Daubländer M, Müller R, Lipp MD. The incidence of complications associated with local anesthesia in dentistry. Anesth Prog. 1997;44: $132-141$.

9. Medix. Local anesthetics: accidents. Encyclopédie Médicale. Available at: http://www.medix.free.fr/sim/anesthesique-locaux.php. Accessed July 26, 2009.

10. Haas DA, Lennon D. A 21 year retrospective study of reports of paresthesia following local anesthetic administration. J Can Dent Assoc. 1995;61:319-320, 323-326, 329-330.

11. Wynn RL, Bergman SA, Meiller TF. Paresthesia associated with local anesthetics: a perspective on articaine. Gen Dent. 2003;51:498.

12. Van Eden SP, Patel MF. Prolonged paraesthesia following inferior alveolar nerve block using articaine. Br J Oral Maxillofac Surg. 2003;41:202. 
13. Lemay H, Dorval G, Nguyen TD. Allergy has no age. $J$ Dent Que. 1991;28:317-320. [French].

14. Gunera-Saad N, Guillot I, Cousin F, et al. Immediate reactions to local anesthetics: diagnostic and therapeutic procedures. Ann Dermatol Venereol. 2007;134:333-336.

15. Schatz M. Adverse reactions to local anaesthetics. Immunol Allergy Clin North Am. 1992;12:585-609.

16. Mazoit JX. Mode d'action et toxicité des anesthésiques locaux. In: Conférences d'actualisation 2002. Congrès national d'anesthésie et de réanimation. Elsevier et SFAR. 2002:287-301. [French].

17. Société Française d'Anesthésie et de Réanimation (SFAR, 2002). SAMU de France. Société francophone de médecine d'urgence. Conférence d'Experts. Pratique des anesthésies locales et locorégionales par des médecins non spécialisés en anesthésie-réanimation, dans le cadre des urgences. 2002, available online from June 13, 2003. [French].

18. Sztark F. Toxicité systémique des anesthésiques locaux. Revue d'Anesthésie-Réanimation et de Médecine d'Urgence. 2009;1(4):1-7.

19. Jenkins JL. Coma, syncope, convulsions et autres troubles de la conscience. Masson Ed. Médecine d'urgence. 1998:344-364. [French].

20. eMedicine. Available at: http://emedicine.medscape.com/article/768268overview. Accessed August 12, 2009. [French].

21. Kopacz DJ, Allen HW. Accidental intravenous levobupivacaine. Anesth Analg. 1999;89:1027-1029.

22. Auroy Y, Narchi P, Messiah A, et al. Serious complications related to regional anesthesia. Results of a prospective survey in France. Anesthesiology. 1997;87:479-486.

23. Brown DL, Ransom DM, Hall JA, et al. Regional anesthesia and local anesthetic-induced systemic toxicity: seizure frequency and accompanying cardiovascular changes. Anesth Analg. 1995;81: 321-328.

24. Eledjam JJ, Gros T, Viel E, et al. Ropivacaine overdose and systemic toxicity. Anaesth Intensive Care. 2000;28:705-707.

25. Zuberi BF, Shaikh MR, Jatoi NU, et al. Lidocaine toxicity in a student undergoing upper gastrointestinal endoscopy. Gut. 2000;46:435.

26. Day RO, Chalmers DR, Williams KM, et al. The death of a healthy volunteer in a human research project: implications for Australian clinical research. Med J Aust. 1998;168:449-451.

27. Septodont. Available at: http://www.septodont.be/secure/produits/html/ septanestn_fr.html. Accessed July 19, 2009.

28. Septodont. Available at: http://www.septodont.be/secure/produits/html/ septanests_fr.html. Accessed July 19, 2009.

29. Septodont. Available at: http://www.septodont.fr/produits/anesthesie/ septanest40/septanest40.html. Accessed August 12, 2009.

30. Bosscher Foundation. The articaine problem. Available at: http://www. bosscherstichting.org/index.php/english/informatie/voor-professioneelgeinteresseerden.html. Accessed December 8, 2009.

31. Rosenman KD, Guss PS. Prevalence of congenital deficiency in serum cholinesterase. Arch Environ Health. 1997;2:42-44.

32. The Bosscher Foundation. Available at: http://www.bosscherstichting. org/index.php/english/informatie/voor-professioneel-geinteresseerden. html. Accessed December 8, 2009.
33. Dower JS Jr. Anesthetic study questioned. J Am Dent Assoc. 2007; 138:708-710.

34. Miller PA, Haas DA. Incidence of local anaesthetic-induced neuropathies in Ontario from 1994-1998. J Dent Res. 2000;79:627.

35. Haas DA. Articaine and paresthesia: epidemiological studies. J Am Coll Dent. 2006;73:5-10.

36. Dower JS Jr. A review of paresthesia in association with administration of local anesthesia. Dent Today. 2003;22:64-69.

37. Milgrom P, Getz T, Silver I. Neuropathic injuries caused by injections. SAFECO property and casualty insurance companies dental claims and insurance news, 2000

38. Dower JS Jr. Articaine vs Lidocaine. J Calif Dent Assoc J. 2007; 35:240.

39. Hillerup S, Jensen R. Nerve injury caused by mandibular block analgesia. Int J Oral Maxillofac Surg. 2006;35:437-443.

40. US Food and Drug Administration Center for Drug Evaluation and Research. Septodont application for approval of Septocaine (articaine) local anesthetic. NDA 20-971. Safety summary: paresthesia section 8.5.3.5, 256-9. Beltsville, MD: US Food and Drug Administration Center for Drug Evaluation and Research; 1998.

41. Pedlar J. Prolonged paraesthesia. Br Dent J. 2003;194:181.

42. Gagnon S, Leblanc S, Malamed SF. Articaine hydrochloride: a study of the safety. J Am Dent Assoc. 2001;132:177-185.

43. Malamed SF, Gagnon S, Leblanc D. Articaine hydrochloride: a study of the safety of a new local anesthetic. J Am Dent Assoc. 2001;132: $177-185$.

44. Campbell JR, Maestrello CL, Campbell RL. Allergic response to metabisulfite in lidocaine anesthetic solution. Anesth Prog. 2001;48: 21-26.

45. Chantaphakul H, Siripassorn K, Ruxrungtham K. Tetracaine challenge test in a multiple local anesthetics sensitive patient. J Allergy Clin Immunol. 2004;113:312-313.

46. Nature. Court tackles whether drug labels shield manufacturers. Available at: http://www.nature.com/news/2008/081104/full/news.2008.1205. html. Accessed June 23, 2011.

47. Dexfenfluramine: procès en France et ailleurs. Revue Prescrire. 2008;28:776-77. [French]. Available at: http://www.prescrire.org/ aLaUne/dossierDexfenfluramine.php.

48. Loi n 98-389 du 19 mai 1998 relative à la responsabilité du fait des produits défectueux Journal Officiel du 21 mai 1998: 7744. En vigueur depuis le 21 Mai 1998. Créé par Loi n98-389 du 19 mai 1998 - art. 1 JORF 21 mai 1998. Available at: http://www.conseil-droitcivil.com/ code-civil/Titre-IV-bis-De-la-responsabilite-du-fait-des-produitsdefectueux..html?PHPSESSID=927507b8a43343b48f88f84595a94fe9. Accessed June 24, 2011.

49. Prescrire Rédaction Dexfenfluramine: condamnation définitive. Rev Prescrire. 2006;26:185. [French].

50. Dexfenfluramine: procès en France et ailleurs. Revue Prescrire. 2008;28:776-77. [French]. Available at: http://www.prescrire.org/ aLaUne/dossierDexfenfluramine.php.
Local and Regional Anesthesia

\section{Publish your work in this journal}

Local and Regional Anesthesia is an international, peer-reviewed, open access journal publishing on the development, pharmacology, delivery and targeting and clinical use of local and regional anesthetics and analgesics. The journal welcomes submitted papers covering original research, basic science, clinical studies, reviews \& evaluations,

\section{Dovepress}

guidelines, expert opinion and commentary, case reports and extended reports. The manuscript management system is completely online and includes a very quick and fair peer-review system, which is all easy to use. Visit http://www.dovepress.com/testimonials.php to read real quotes from published authors. 